\title{
STRATEGI PEMBANGUNAN EKONOMI YANG ISLAMI MENURUT FAHIM KHAN
}

\author{
Ali Murtadho \\ UIN Walisongo Semarang \\ amalridho@gmail.com
}

\begin{abstract}
Several theories about the development strategy formulated by the most conventional neoclassical economists much criticized. Fabim Khan including contemporary Islamic economic thinkers who criticize conventional economic development strategy with alternative bids from the Islamic economics perspective. Their thinking is exciting to examined substance and its correlation with the economic development of contemporary Islamic discourse that dominated the development of financial institutions/syariah banking. The creation of entrepreneurial opportunities made Fabim Khan as a keyword in the concept of criticizing conventional strategy and supporting the Islamic economic development strategy. Strategy opened and graced this productive creative independent businesses are deemed appropriate and supported by the Islamic economic system based on profit and loss sharing partnership (profit-loss sharing). The idea is to promote excellence banking system of sharing based on the conventional interest-based banking system in spurring economic development suplus to enliven the entrepreneurial workforce.
\end{abstract}

Keywords: Economic development strategy; profit and loss sharing; entrepreneurship.

\section{Pendahuluan}

Beberapa teori tentang strategi pembangunan di negara yang mengalami problem kependudukan kebanyakan dirumuskan oleh para ekonom konvensional yang banyak dibingkai paham kapitalisme. Namun gagasan tersebut tidak terlepas dari berbagai sorotan kritis. Ekonomi neoklasikal yang liberalistik dengan bersendikan fundamentalisme pasar dinilai hanya berorientasi pada penciptaan pertumbuhan ekonomi dengan keyakinan bahwa hanya dengan pertumbuhan ekonomi yang tinggi masalah ketenagakerjaan dan kesejahteraan rakyat dapat teratasi. ${ }^{1}$ Teori ini dikritik

\footnotetext{
1 Sri-Edi Swasono, Menolak Neoliberalisme dan Membangun Ekonomi Nasional, Yogyakarta: PUSTEP-UGM, 2010, hlm. 49.
} 
karena mengabaikan aspek pemerataan dan pengembangan produktivitas mayoritas kaum miskin. ${ }^{2}$

Dalam jajaran para pemikir ekonomi Islam, kritik terhadap strategi pembangunan barat disertai tawaran alternatif dari perspektif ekonomi Islam dilontarkan oleh Fahim Khan, ketua Pusat Bisnis Islam Universitas Internasional Riphah Pakistan, aktivis dan pernah menjadi direktur Islamic Research and Training Institute (IRTI). Pemikiran Fahim Khan berangkat dari keprihatinannya terhadap strategi konvensional dalam mengatasi problematika pengangguran terutama di negara-negara yang sedang berkembang yang berupaya memacu pembangunan ekonomi. Fokus perhatian strategi tersebut bertumpu pada masalah banyaknya surplus tenaga kerja serta kondisi upah yang memprihatinkan.

Tulisan ini mengungkap kejelasan konsep Fahim Khan mengenai strategi pembangunan ekonomi Islam pada negara yang berkelimpahan penduduk (sumber daya manusia) meliputi latar belakang formulasinya, pendekatan yang dipakai, serta korelasinya secara substansial dengan diskursus ekonom pembangunan kontemporer dan konsep operasional lembaga keuangan/perbankan syari'ah.

\section{Konsep Fahim Khan tentang Strategi Pembangunan Ekonomi}

Muhammad Fahim Khan banyak terlibat di bidang pengembangan dan aplikasi ekonomi dan keuangan Islam baik sebagai peneliti, pengajar maupun sebagai penasehat pemerintah di bidang ekonomi Islam dan keuangan Islam selama 25 tahun terakhir. ${ }^{3}$ Selama karier profesionalnya, Fahim Khan menggeluti berbagai bidang, antara lain bidang pembangunan ekonomi, perdagangan asing dan ekonomi internasional, keuangan dan perbankan, investasi dan analisis finansial, migrasi tenaga kerja internasional, ekonomi dan keuangan Islam, statistika dan ekonometrika. Ia juga memimpin berbagai uji coba terkait pengembangan model-model ekonometrika bagi

2 Mahbub ul-Haq, Reflections on Human Development: How The Focus of Development Economics Shifted from National Income Accounting to People Centred Policies, Told by One of The Chief Architects of The New Paradigm, New York: Oxford Univ. Press, 1995, hlm. 8.

3 Lihat: "Authors' Biography", Journal of Islamic Economics, Banking and Finance, Volume 6, Number 2, hlm. 117. 
perencanaan dan proyeksi ekonomi makro, juga memimpin riset terkait berbagai isu kebijakan ekonomi makro. ${ }^{4}$

Menurut Fahim Khan solusi problem ekonomi surplus tenaga kerja memang dapat ditangani melalui dua strategi. Pertama, strategi menciptakan kesempatan kerja berupah tetap. Kedua, strategi menciptakan peluang kewirausahaan. Sayangnya strategi pembangunan ekonomi padat penduduk dalam kerangka konvensional hanya memfokuskan pada strategi yang pertama, yaitu berupaya dengan berbagai cara untuk menciptakan kesempatan kerja berupah tetap bagi tenaga kerja secepat-cepatnya dan sebanyakbanyaknya. Strategi ini membutuhkan para kapitalis untuk berinvestasi memperluas lapangan pekerjaan. Para kapitalis ini cenderung memakai surplus sumber daya manusia untuk dipekerjakan bukan untuk dilibatkan dalam aktivitas kewirausahaan. Strategi konvensional ini cenderug mengabaikan strategi penciptaan peluang kewirausahaan sebagai solusi problem ekonomi surplus tenaga kerja. ${ }^{5}$

Secara umum kualitas sumber daya manusia di negara-negara berkembang masih rendah, baik dari sisi pendidikan maupun skill manajemen kewirausahaannya. Memberikan peluang wirausaha kepada mereka bukan berarti menyediakan pabrik besar atau toko besar untuk dikelola. Memberikan peluang kewirausahaan berarti memberikan kesempatan kepada mereka untuk melakukan usaha yang dapat mereka kelola sendiri. Misalnya membuka peluang atau menfasilitasi mereka yang memiliki ketrampilan dasar entah sebagai tukang kayu, penjahit, tukang bangunan, tukang bikin makanan kecil dan sebagainya untuk mendirikan unit manufaktur kecil yang mempekerjakan beberapa orang saja yang mungkin anggota keluarga mereka sendiri. Kesuksesan usaha bukan milik mereka yang berpendidikan tinggi saja, tidak jarang ada orang yang buta huruf dan tidak berpendidikan sukses menjalankan usaha kecil-usaha kecil dengan penghasilan yang tidak kalah dari gaji tetap pegawai atau karyawan. Bahkan dewasa ini banyak diwacanakan

4 Lihat: Biodata of Dr. Fahim Khan-IRTI Publication, http://www.irtipms.org/ Fahim\%20Khan_E.asp, diakses 10 September 2014.

${ }^{5}$ Fahim Khan, Essays in Islamic Economics, Leicester: The Islamic Foundation, hlm. 198. 
dalam beberapa literatur tentang pentingnya pengembangan industri skala kecil. $^{6}$

Fahim Khan mengambil contoh kasus di Pakistan dan Indonesia sebagai negara dengan kondisi ekonomi berlimpah tenaga kerja. Di negaranegara ini orang menganggur bukan karena tidak mau bekerja, tetapi karena mereka tidak mendapatkan pekerjaan sesuai apa yang mereka bisa kerjakan. Dengan pendapatan perkapita yang masih rendah, tentu orang-orang ini memiliki keinginan kuat untuk meningkatkan taraf kehidupan yang lebih baik dengan bekerja. Ketika tidak ada penawaran pekerjaan, mereka tidak dapat menjalankan bisnis atau usaha mandiri karena tidak memiliki modal sendiri. Pada umumnya negara dengan surplus tenaga kerja, sebagian besar sumber daya manusianya tidak memiliki modal. Mereka membutuhkan pinjaman modal jika ingin melakukan usaha mandiri. ${ }^{7}$

Strategi membuka peluang kewirausahaan bagi surplus sumber daya manusia memerlukan beberapa prasyarat sebagai berikut:

a. Ketersediaan modal yang diperlukan oleh surplus tenaga kerja dalam memulai usaha mandiri.

b. Adanya sistem yang dapat menjamin pembagian risiko yang adil antara pemilik modal dan pengusaha.

c. Adanya sistem penjaminan sosial yang dapat menopang dan membimbing kehidupan pelaku usahahingga mereka meraih kesuksesan berwiraswasta. $^{8}$

Ketiga prasyarat tersebut dipakai Fahim Khan untuk memperbandingkan antara sistem konvensional berbasis bunga dengan sistem ekonomi Islam berbasis bagi hasil dalam mendorong strategi menciptakan peluang kewirausahaan.

Sistem ekonomi non-Islam yang berbasis bunga dinilai tidak berhasil mewujudkan prasyarat-prasyarat di atas terutama di negara-negara berkembang yang berpenduduk padat. Sistem berbasis bunga dipandang tidak

\footnotetext{
${ }^{6}$ Ibid.

${ }^{7}$ Ibid., hlm. 198-199.

8 Ibid., hlm. 199.
} 
menyediakan modal yang dibutuhkan oleh calon wirausahawan potensial yang akan memulai usaha. Sistem ini lebih tertarik untuk membiayai usaha mapan yang dapat memastikan terhindar dari kredit macet dan berbagai risiko pembiayaan. Pengajuan pembiayaan oleh orang baru akan memulai usaha biasanya menuntut dipenuhinya persyaratan yang sulit termasuk jaminan yang kadang tidak dapat dipenuhi oleh calon pelaku usaha. Dalam kondisi ini tentu ia akan lebih memilih untuk mencari kerja berupah tetap dari pada melakukan usaha mandiri yang sulit dan berisiko.?

Fahim Khan berkali-kali menegaskan kejelasan strategi pembangunan ekonomi dalam perspektif Islam yang menekankan lebih pentingnya pengaturan institusional untuk secara langsung melibatkan orang dalam kegiatan kewirausahaan mereka sendiri daripada strategi memanjakan kapitalis untuk menciptakan kesempatan kerja dengan upah pasti di pasar kerja. Ekonomi Islam memiliki mekanisme built-in untuk mendukung strategi tersebut. Mekanisme yang sudah built-in ini dapat lebih diperkuat dengan langkah-langkah berikut:

1. Kemampuan kewirausahaan adalah modal sumber daya manusia yang harus dikembangkan oleh pendidikan yang tepat. Perencanaan pendidikan yang tepat dapat berkontribusi banyak untuk mengurangi risiko wirausaha dengan terciptanya iklim sosial yang kondusif serta kesadaran bersama untuk mentaati segala aturan main. Tidak hanya pendidikan komersial, pendidikan Islam memiliki peranan penting yang tidak boleh diabaikan untuk menciptakan iklim sosial yang mendukung bisnis konstruktif serta menanamkan etika dan moral masyarakat.

2. Perluasan akomodasi finansial melalui sistem perbankan dapat berfungsi sebagai alat yang efektif untuk meningkatkan pembiayaan bagi sumber daya manusia enterprener. Efisiensi sistem perbankan dalam menyediakan pembiayaan tersebut dalam kerangka Islam mensyaratkan reformasi substansial tidak hanya dalam struktur perbankan yang ada, tetapi pada seluruh sektor fiskal dan moneter. Dalam kerangka Islam, bank dan lembaga keuangan seharusnya diminta untuk menawarkan akomodasi keuangan hanya untuk pengusaha. Pinjaman konsumtif dari

\footnotetext{
${ }^{9}$ Ibid., hlm. 199-200.
} 
Strategi Pembangunan Ekonomi...

perbankan komersial hampir tidak ada karena pinjaman ini harus berupa qardh hasan (pinjaman tanpa bunga atau tanpa bagi hasil)

3. Institusi Islam hisbah harus dihidupkan kembali untuk mengawasi secara efektif norma-norma keadilan sosial ekonomi dalam perekonomian. Harga, sewa, alat-alat produksi, struktur produksi, struktur upah, pasar dan fungsinya, dan sebagainya, semua masuk dalam lingkup pengawasan lembaga ini. ${ }^{10}$

\section{Latar Belakang Konsep Fahim Khan dan Pendekatan yang Dipakai}

Tulisan Fahim Khan dilatarbelakangi oleh pengamatannya terhadap kegagalan strategi pembangunan ekonomi di negara-negara sedang berkembang yang mengadopsi teori-teori pembangunan ekonomi yang dirumuskan oleh ahli ekonom barat. Ia secara khusus menyebut Indonesia, Bangladesh dan Pakistan. Dalam kasus di Indonesia misalnya, stratregi pembangunan yang dipakai adalah strategi neo-klasik yang diusung oleh Robert Solow, Paul Samuelson dan juga Milton Friedmann. Strategi ini menitikberatkan pada pembangunan berpola industrialisasi secara besarbesaran dengan keyakinan akan adanya trickle down effect (efek rambatan) yang dapat mewujudkan kesejahteraan rakyat. Strategi ini dibuktikan dengan suksesnya Program Marshall Plan dalam rekonstruksi negara-negara Eropa Pasca Perang Dunia II. ${ }^{11}$

Konsep Fahim Khan juga dilatarbelakangi terjadinya akumulasi modal besar-besaran sebagai konsekuensi dari strategi industrialisasi tersebut. Penciptaan lapangan kerja lewat melalui industrialisasi ini memerlukan akumulasi modal melalui mobilisasi tabungan atau bahkan dengan pinjaman dari luar negeri. Kalangan pemodal diharapkan dapat berinvestasi sebesarbesarnya. Diperlukan kebijakan yang dapat meningkatkan keuntungan

\footnotetext{
${ }^{10}$ Ibid., hlm. 208.

11 Wahyu Budi Nugroho, "Industrialisasi Orde Baru Tumbuh dengan Kemiskinan", http://kolomsosiologi.blogspot.com/2011/03/industrialisasi-orde-baru.html, diakses 12 Maret 2011.
}

6 - Economica

Volume VII/ Edisi 2/Oktober 2016 
kelompok kapitalis ini dengan berbagai insentif fiskal dan moneter dengan tetap mempertahankan upah dalam tingkat minimal. ${ }^{12}$

Kegagalan strategi tersebut dalam analisis Fahim Khan karena lebih terfokus pada penyerapan tenaga kerja sektor formal yang mensyaratkan investasi besar dari kalangan pemodal. Strategi ini kurang mendukung ketersediaan peluang kewirausahaan rakyat yang mandiri. Penilaian akan kegagalan tersebut memunculkan konsep Fahim Khan tentang strategi pembangunan ekonomi Islam. Penciptaan peluang kewirausahaan dijadikan Fahim Khan sebagai kata kunci dalam konsepnya yang mengkritisi strategi konvensional dan mendukung strategi pembangunan ekonomi Islam.

Paling tidak ada tiga konteks yang melatarbelakangi konsep Fahim Khan. Pertama, konteks latar belakang kehidupan dan akademiknya. Kedua, tren pembangunan ekonomi kontemporer. Dan ketiga, tren pengembangan ekonomi Islam. Setting latar belakang pendidikan Fahim Khan yang memiliki dasar keilmuan statistik di jenjang kesarjanaan awalnya, yang kemudian dikembangkan dengan bidang ilmu ekonomi serta keterlibatannya dalam pembuatan berbagai model, ikut memberi warna konsepnya yang sangat memerhatikan model matematika. Model matematika terkesan mensimplifikasi masalah dalam persamaan dan angka.

Dalam merumuskan gagasan ekonomi Islamnya, Fahim Khan memakai metode pemikiran retrospektif, sebagaimana dipakai oleh kebanyakan pemikir ekonomi Islam kontemporer. Metode ini berangkat dari penelaahan terhadap problematika ekonomi di dunia Islam dan berusaha mencari berbagai pemecahan terhadap persoalan-persoalan ekonomi umat dengan kembali kepada Al-Qur'an dan Sunnah untuk mencari dukungan atas pemecahan-pemecahan tersebut dan mengujinya dengan memerhatikan petunjuk Tuhan. ${ }^{13}$ Pendekatan yang dipakai oleh Fahim Khan ini karena ia berupaya mencari solusi dengan memakai aturan normatif ekonomi Islam yang ia interpretasikan dalam model ekonomi makro.

${ }^{12}$ Fahim Khan, Essays..., hlm. 197-198.

13 Monzer Kahf, The Islamic Economy: Analytical of The Functioning of The Islamic Economic System, terj. Machnun Husein, "Ekonomi Islam (Telaah Analitik terhadap Fungsi Sistem Ekonomi Islam), Yogyakarta: Pustaka Pelajar, 1995, hlm. 12. 


\section{Analisis Implementasi Gagasan Fahim Khan dalam Diskursus Pembangunan Ekonomi Kontemporer}

Dalam diskursus ekonomi pembangunan kontemporer, sebagaimana ditulis Wahyu Nugroho, muncul dua strategi pembangunan ekonomi. Yaitu strategi strukturalis dan strategi neo-klasik. Strategi pembangunan model strukturalis menekankan perombakan masyarakat terkait sistem, kelembagaan, institusi-institusi sosial bahkan kehidupan demokrasi di dalamnya. Setelah perombakan-perombakan tersebut berjalan dengan baik dan sesuai (semisal terminimalisirnya pihak-pihak yang dirugikan) barulah pembangunan ekonomi dijalankan. Sedangkan strategi neo-klasik menitikberatkan pada pembangunan berpola industrialisasi secara besar-besaran dengan keyakinan akan adanya trickle down effect (efek rambatan) yang dapat mewujudkan kesejahteraan rakyat. Strategi ini dibuktikan dengan suksesnya Program Marshall Plan dalam rekonstruksi negara-negara Eropa Pasca Perang Dunia II. ${ }^{14}$

Gagasan Fahim Khan merupakan konsep ideal yang ditawarkan untuk mengatasi problem kelebihan tenaga kerja dalam rangka pembangunan ekonomi menuju kesejahteraan penduduk. Fahim Khan hanya menyoroti strategi neo-klasik yang digambarkannya hanya terfokus pada upaya memperluas kesempatan kerja agar secara cepat dapat menyerap seluruh tenaga kerja yang berlimpah. Strategi tersebut dinilai Fahim Khan tidak berhasil memenuhi harapan mencapai titik balik atau tinggal landas sebagaimana direncanakan. ${ }^{15}$

Kegagalan strategi tersebut dalam penilaian Fahim Khan penyebabnya sederhana, yakni menyederhanakan strategi pembangunan ekonomi surplus tenaga kerja hanya pada upaya pembangunan yang difokuskan pada percepatan penyerapan tenaga kerja dengan menciptakan sebayak-banyaknya lapangan kerja dengan upah/gaji tetap. ${ }^{16}$ Dalam konsep Fahim Khan tujuan pembangunan nasional seharusnya untuk menghasilkan peluang-peluang yang pertama kali menyerap surplus sumber daya manusia menuju ke titik balik

\footnotetext{
14 Nugroho, "Industrialisasi...

${ }^{15}$ Fahim Khan, Essays..., hlm. 98.

${ }^{16}$ Ibid.
} 
atau tinggal landas, setelah itu surplus sumber daya manusia yang tersisa menjadi terdorong untuk terserap ke dalam sistem. ${ }^{17}$

Strategi penekanan kewirausahaan Fahim Khan tersebut tentu tidak terlepas dari tren perkembangan ekonomi makro atau ekonomi pembangunan kontemporer. Dalam kajian ekonomi makro kontemporer ditekankan pentingnya posisi pengusaha dalam pembangunan ekonomi. Luasnya kegiatan ekonomi yang dilakukan suatu negara bergantung kepada jumlah pengusaha dalam ekonomi. Apabila tersedianya pengusaha dalam jumlah tertentu penduduk adalah lebih banyak, lebih banyak kegiatan ekonomi yang dijalankan. ${ }^{18}$ Kewirausahaan menjadi faktor penting yang menyebabkan pertumbuhan ekonomi. ${ }^{19}$

Faim Khan, sebagaimana para ahli ekonomi Islam lainnya menguatkan teori bahwa Islam dengan ajaran yang dibawanya dan institusi-institusi yang dimunculkannya, memiliki kontribusi positif bagi pertumbuhan dan pembangunan ekonomi. Monzer Khahf ${ }^{20}$ misalnya melihat bahwa ajaran Islam yang terkait dengan zakat, larangan riba serta pola kemitraan dalam musyarakah/mudhärabah, dapat menjadi strategi riil untuk meningkatkan produktivitas masyarakat. Bahkan Maya Shatzmiller dalam artikelnya Economic Performance and Economic Growth in the Early Islamic World dengan menelaah peran instiusi-institusi Islam pada periode-periode pertumbuhan ekonomi menyatakan bahwa ada kejelasan indikator yang menunjukkan bahwa aturan ekonomi Islam dan institusi-institusinya mendukung dan sama sekali tidak menghalangi pertumbuhan ekonomi. Artikel Maya membantah Greif dan Timur Kuran yang menganggap aturan dan institusi Islam tidak berhasil mematerialisasikan pertumbuhan ekonomi. ${ }^{21}$

\footnotetext{
${ }^{17}$ Ibid., hlm. 202.

18 Sadono Sukirno, Makro konomi Teori Pengantar, edisi ketiga, Jakarta: PT RajaGrafindo Persada, 2006, hlm. 430.

19 Daniel Smith, "The Role of Entrepreneurship in Economic Growth", Undergraduate Economic Review, Vol. 6 [2010], Iss. 1, Art. 7, Digital Commons @ IWU, 2010, p. 1, http:/ /digitalcommons.iwu.edu/cgi/ viewcontent.coi?article $=1064 \&$ context=uer, diakses 8 Agustus 2014.

${ }^{20}$ Kahf, The Islamic Economy..., hlm. 75-95.

${ }^{21}$ Maya Shatzmiller, "Economic Performance and Economic Growth in the Early Islamic World", Journal of the Economic andSocial History of the Orient, 54 (2011) 132-184.
} 
Dukungan Fahim Khan terhadap ekonomi Islam lebih pada dukungan formalitas pembelakuan fiqh muamalah dari pada prinsip atau nilai ekonomi Islam dengan aplikasi yang lebih efektif komprehensif. Penekanan pada sisi formalitas ini nampak pada apa yang ia maksudkan dengan bagi hasil. Ia hanya mempromosikan bagi hasil atau kemitraan dengan format mudhärabah atau musyärakah. Ia tidak mencoba mengimplementasikannya dengan lebih luas dan berimbang. Konsep Fahim Khan masih kental normatifnya. Ia membuat batasan hitam puth antara sewa dengan kemitraan. Fahim Khan kurang memerhatikan inovasi aplikasi nilai kemitraan sacara fungsional. Ia masih berkutat pada normativitas syirkah dan mudhärabah. Padahal di Jepang yang bukan negara Islam saja berhasil mengartikulasikan prinsip kemitraan ini pada bidang hubungan antara pekerja dan perusahaan. Prinsip sewa telah diramu dengan prinsip kemitraan. Gerakan produktivitas Jepang menunjukkan bagaimana kerjasama atau bagi hasil diimplementasikan di antara pekerja dan yang mempekerjakan. Berbeda dengan ilmu ekonomi klasik yang memandang tenaga kerja manusia sebagai bagian dari unsur pokok produksi di samping modal dan tanah, konsep produktivitas Jepang menekankan bahwa bahwa manusia secara alamiah membuat barang dan jasa yang diperlukan untuk hidup. Sedangkan tanah, modal dan teknologi adalah alat untuk produksi. Manusia harus memainkan peranan utama dalam memanfaatkan nilai guna dari ketiga unsur tersebut. Perusahaan perlu memerhatikan dimensi sosial kerjasama kerja sama antar tenaga kerja. Tenaga kerja harus dipandang sebagai prioritas di atas modal, tanah dan teknologi. Di sini, tenaga kerja merupakan bentuk keunikan tingkah laku dari jenis manuisia dan meningkatkan produktivitas dengan memperbaiki kondisi kerja merupakan landasan bagi pengisian hidup secara baik serta memberikan "arti" bagi kehidupan manusia. 22

Strategi pembangunan dengan gerakan produktivitas model Jepang memiliki persamaan dengan prinsip maqūshid al-syarí'ah fi al-iqtishäd, utamanya prinsip kebersamaan, persatuan dan tolong menolong (al-jamăah wa al-I'tiläf wa al-ta'awun). Artinya dengan menerapkan semangat kebersamaan dan semangat berbagi yang diterapkan pada hubungan antara pengusaha dan

${ }^{22}$ J. Ravianto, Orientasi Produktivitas dan Ekonomi Jepang, Apa Yang Harus Dilakukaan Indonesia?, Jakarta: UI Press, 1986, hlm. 32. 
karyawan membuahkan semangat kerjasama yang berimbas pada kenaikan produktivitas yang dinikmati bersama.

Strategi yang demikian masih luput dari gagasan Fahim Khan. Fahim Khan menyederhanakan strategi pembangunan ekonomi hanya pada persoalan membuka peluang kewirausahaan bagi surplus sumber daya manusia, yang mensyaratkan ketersediaan modal untuk memulai usaha mandiri dalam sistem profit and loss sharing yang dapat menjamin pembagian risiko yang adil antara pemilik modal dan pengusaha, serta adanya sistem penjaminan sosial yang dapat menopang dan membimbing kehidupan pelaku usaha hingga mereka meraih kesuksesan berwiraswasta. ${ }^{23}$

Apa yang disebutkan Fahim Khan ini adalah diberlakukannya musyärakah dan mudhärabah sebagai pengganti sistem bunga. Padahal pemberlakuan mudhärabah membutuhkan kondisi masyarakat yang kondusif agar mudhärabah memberi maslahah. Bahkan khazanah fiqh klasik telah memperingatkan hal ini. Dalam Kitab al-Fiqh 'alā Madzāhib al-Arba'ah ditegaskan bahwa dalam pelaksanaan mudhärabah disyaratkan empat hal yakni sifat amanah, keahlian/skill usaha yag baik, kejujuran dan keikhlasan. Keempat unsur ini yang dapat menjamin diberlakukannya mudhärabah yang membawa hasil. Jika tidak ada keempat unsur ini maka aplikasi mudhārabah dapat menimbulkan pemubaziran harta. Bahkan ditegaskan bahwa mudhārabah dilarang ketika pihak yang terlibat tidak amanah, tidak efisien dan tidak memiliki keahlian mengelola dana. ${ }^{24}$

Strategi Fahim Khan belum sampai kepada kendala yang dihadapi yang secara empiris terjadi ketika digalakkan usaha berbasis bagi hasil. Tidak sedikit orang yang tertarik dan terdorong melakukan usaha tetapi tidak mencapai kesuksesan yang diharapkan bukan karena tidak ada peluang tetapi karena ada faktor lain yang lebih mendasar. Salah satunya diungkap oleh Musa Asy'arie. Dalam pembinaan pembinaan industri kecil dan menengah, banyak menghadapi masalah terkait keterbatasan dalam akses pasar, sumbersumber pembiayaan dan permodalan, penguasaan teknologi dan informasi,

\footnotetext{
${ }^{23}$ Fahim Khan, Essays..., hlm. 199.

24 'Abd al-Rahman Al-Jazairi, Kitab al-Fiqh 'alā Mažhāhib al-Arba'ah, Juz III, Beirut: Dār alKutub al-'Ilmiyyah, 1990, hlm. 36.
} 
keterbatasan dalam organisasi dan manajemen, serta pengembangan jaringan usaha dan kemitraan antara pelaku ekonomi yang ada. Di atas itu semua Musa Asy'ari mengungkap adanya persoalan mendasar yang mengurung pelaku usaha sehingga sulit untuk keluar dari banyak masalah tersebut. Meski banyak bantuan tersedia dan ada niat yang besar dari dalam diri mereka namun terasa berat untuk melangkah maju. Persoalan mendasar yang mengurung ini lebih bersifat kultural, yaitu sistem nilai budaya yang telah membentuk kepribadian pelaku usaha yang sudah berjalan puluhan tahun. Sistem nilai budaya ini memengaruhi cara pelaku usaha tersebut menjalankan usaha (manajemen), seperti cara dalam bekerja, menghadapi mitra bisnisnya, menangani karyawan, mengelola uang, menggunakan keuntungan, menghadapi pesaing dan bertahan menghadapi perubahan dan menghadapi krisis. ${ }^{25}$

Diperlukan strategi pendekatan yang yang fundamental, terpadu dan berkelanjutan untuk membina dan memberdayakan para pelaku usaha kecil antara lain pendekatan kultural. Pendekatan ini memandang perlunya memahami setting budaya di mana industri itu tumbuh berkembang. Sebagai contoh lingkungan pedesaan berpengaruh membentuk pola budaya agraris, sementara tantangan yang dibawa oleh dunia industri mengharuskan adanya basis budaya industri yang inovatif, tepat waktu, akurat dan konsisten pada mutu yang terjaga secara konstan, responsif terhadap tuntutan persaingan, terbuka terhadap perubahan dan persaingan yang makin ketat. Perbedaan budaya ini terlihat dalam cara memandang uang, waktu dan teknik. Dalam budaya agraris waktu dipandang sebagai gerak siklus sedangkan dalam budaya industrial dipandang sebagai gerak linier. Dalam budaya agraris uang lebih bermakna sosial sementara dalam budaya industrial lebih bermakna ekonomi. Teknologi dalam budaya agraris dipandang sebagai prestise sehingga tidak optimal pemanfaatannya sementara budaya industri menuntut pemanfaatan tekonologi yang canggih, optimal dan rasional. ${ }^{26}$

Fahim Khan tidak banyak menjelaskan pra-kondisi masyarakat untuk diberlakukannya sistem bagi hasil sebagaimana disebutkan dalam persyaratan mudhärabah. Padahal penyiapan kondisi masyarakat baik secara skill maupun

\footnotetext{
${ }^{25}$ Musa Asy'arie, Keluar dari Krisis Multi Dimensi, Yogyakarta: LESFI, 2001, hlm. 124.

${ }^{26}$ Ibid., hlm. 124-132.
} 
moral yang kondusif untuk usaha produktif ini sangat penting. Beberapa negara Islam sangat memerhatikan strategi ini. Saudi Arabia misalnya, berkembang cukup dramatis. Di tahun 1960-an kebanyakan penduduknya adalah nomaden atau semi nomaden. Arab Saudi melakukan strategi pembangunan dengan proyek utama mentransformasikan penghasilan minyak untuk membentuk negara industri modern dengan tetap mempertahankan nilai-nilai tradisional Islam. Terjadi impor tenaga kerja besar-besaran. Persoalan yang dihadapi adalah mendidik tenaga kerja domestik berkeahlian. Minyak adalah sumberdaya manusia yang tidak dapat diperbaharui. ${ }^{27}$

Tidak disebutkannya strategi pembangunan sumber daya manusia yang kondusif barangkali karena titik bidik Fahim Khan lebih pada upaya mempromosikan sistem ekonomi Islam berbasis bagi hasil sebagai alternatif sistem ekonomi konvensional berbasis bunga. Ini menyebabkan gagasan Fahim Khan tersebut terkesan kurang komprehensif bila dikaitkan dengan wacana kontemporer pembangunan ekonomi.

\section{Konsep Fahim Khan dan Pengembangan Ekonomi Islam di Bidang Perbankan}

Kesemarakan pemikiran ekonomi Islam modern terpicu oleh tumbuh kembangnya perbankan Islam yang merupakan realisasi dari gagasan untuk membentuk kembali perekonomian berdasarkan Islam. Gagasan ini terkait dengan semangat kebangkitan kembali Islam di mana keuangan, perbankan dan investasi menjadi garapan terpenting dalam proses Islamisasi ekonomi. Perbankan modern berbasis bunga ditolak dan dianggap tidak Islami karena adanya larangan Al-Qur'an terhadap riba yang dimaknai sebagai larangan terhadap bunga. ${ }^{28}$ Sistem keja sama berdasarkan prinsip bagi hasil dipakai sebagai alternatif dasar bagi dunia perbankan dan investasi dalam perspektif Islam. ${ }^{29}$

\footnotetext{
${ }^{27}$ Michael P. Todaro, Economic Development, Edisi VI, New York: Addison-Wesley Publishing Company, Inc., 1997, hlm. 664-665.

${ }^{28}$ Muhammad Nejatullah Siddiqi, Issues in Islamic Banking, terj. Asep Hikmat Suhendi dari judul asli "Bank Islam", Bandung: Penerbit Pustaka, 1984, hlm. xiii.

${ }^{29}$ Ibid., hlm. xiii.
} 
Dalam semangat penyemarakan bank syariah tersebut pemikiran Fahim Khan hadir. Gagasannya mempromosikan keunggulan sistem ekonomi Islam berbasis bagi hasil atas sistem ekonomi konvensional berbasis bunga dalam memacu pembangunan ekonomi suplus tenaga kerja. Konsep Fahim Khan tentang formulasi Islam tentang strategi pembangunan ekonomi di negara-negara yang mengalami surplus tenaga kerja tersebut mengasumsikan kondisi-kondisi ideal sebagaimana yang ia gambarkan dari aturan-aturan normatif ekonomi Islam. Poros dari aturan normatif yang ia jadikan prinsip dasar adalah prinsip bagi hasil dan prinsip anti riba (bunga) sebagai fondasi bangunan ekonomi Islam.

Fahim Khan mengkritik sistem ekonomi berbasis bunga yang menekankan solusi penanganan problem ekonomi surplus tenaga kerja melalui strategi menciptakan kesempatan kerja berupah tetap. Strategi konvensional ini hanya berupaya dengan berbagai cara untuk menciptakan kesempatan kerja berupah tetap bagi tenaga kerja secepat-cepatnya dan sebanyak-banyaknya. Strategi ini membutuhkan para kapitalis untuk berinvestasi memperluas lapangan pekerjaan. Para kapitalis ini cenderung memakai surplus sumber daya manusia untuk dipekerjakan bukan untuk dilibatkan dalam aktivitas kewirausahaan. Strategi konvensional ini cenderung mengabaikan strategi penciptaan peluang kewirausahaan sebagai solusi problem ekonomi surplus tenaga kerja. ${ }^{30}$

Fahim Khan meyakini bahwa institusi ekonomi Islam dengan perbankan syariahnya memiliki pengaruh kuat untuk menciptakan dan mendorong kegiatan kewirausahaan dalam perekonomian. Keharaman riba merupakan pengaturan institusional yang memaksa salah satu sumber daya yang langka dalam perekonomian (yakni modal finansial) untuk aktivitas kewirausahaan daripada disewakan untuk memperoleh sewa modal. Fahim Khan menegaskan bahwa modal keuangan dilarang keras untuk memperoleh sewa, yaitu bunga. Satu-satunya cara agar modal keuangan dapat menghasilkan pendapatan adalah dengan melibatkannya dalam aktivitas kewirausahaan di mana keuntungan yang akan diperoleh merupakan imbalan risiko kerugian produktif. Membiarkan modal finansial menganggur juga tidak

\footnotetext{
${ }^{30}$ Fahim Khan, Essays..., hlm. 198.
} 
disukai. Ada beban pungutan zakat atas sumber daya jika tidak digunakan dalam kegiatan-kegiatan produktif. ${ }^{31}$ Modal finansial tidak dapat menghasilkan apa-apa tanpa melibatkan sumber komplementer. Sumber daya komplementer yang terbaik adalah sumber daya manusia, terutama ketika sumber daya manusia ini sangat banyak sehingga modal finansial dapat menegosiasikan rasio bagi-hasil yang lebih baik. Dengan demikian, pengaturan institusional Islam seperti perbankan syariah ini tidak hanya memaksa sumber daya finansial untuk menjadi sumber daya wirausaha, tetapi juga menciptakan permintaan sumber daya manusia. ${ }^{32}$

Sistem ekonomi Islam dengan institusi filantropisnya yang menjamin kebutuhan hidup minimal dan sistem perbankan syariahnya yang tidak memakai bunga. Dalam sistem ini, individu yang berwirausaha menghadapi risiko yang jauh lebih sedikit. Risiko akan dibagi antara pelaku wirausaha dan pemilik modal finansial. Risiko finansial bahkan ditanggung sepenuhnya oleh para pemilik modal finansial. Ketika terjadi kerugian, tidak ada kewajiban untuk mengembalikan modal. Pelaku usaha sudah mempertaruhkan sumber daya manusia yang dimilikinya. Ketika terjadi kebangkrutan usaha, tidak ada ketakutan kelaparan karena masyarakat menjamin kebutuhan pokoknya. Dalam suasana yang demikian, sumber daya manusia akan lebih tertarik mencari kegiatan kewirausahaan dari pada pekerjaan dengan upah tetap. Mereka akan memiliki pekerjaan tetap sebatas sampai mereka dapat menemukan modal finansial yang diperlukan untuk memulai kegiatan kewirausahaan. ${ }^{33}$

Namun demikian, idealitas perbankan syariah berbasis bagi hasil tersebut berhadapan dengan realitas operasional perbankan syariah terutama dari sisi pembiayaan. Dalam konsep fiqh yang digunakan dalam merumuskan operasionalisasi perbankan syariah ada dua kategori prinsip/metode pembiayaan yakni model penyertaan modal dengan prinsip bagi hasil (prinsip mudhärabah/musyärakah) dan prinsip mark-up \& fee (pengambilan keuntungan

\footnotetext{
31 Ibid., hlm. 203.

${ }^{32}$ Ibid.

${ }^{33}$ Ibid.
} 
dan upah). ${ }^{34}$ Sebagai lembaga bisnis, untuk tetap eksis bank syariah dituntut dapat menghasilkan keuntungan dengan tetap berlabelkan Islam/berpijak pada aturan-aturan hukum Islam. Sudah barang tentu dalam pembiayaan bank syariah lebih memilih memakai akad muräbahah atau ijärah dengan prinsip mark-up \& fee (pengambilan keuntungan dan upah) dari pada memakai akad mudhärabah atau musyärakah yang berbasis prinsip bagi hasil yang tidak memberi kepastian keuntungan di muka.

Terhadap banyaknya pilihan akad dalam perbankan syariah yang memudahkan bank memakai prinsip yang bukan berbasis bagi hasil ini, Fahim Khan justru apresiatif dan tidak memberikan kritikan. Ia malah terkesan mendukung dengan pernyataannya:

"It, however, does not mean that the other financing techniques are less important and need to be discarded. They have their own uses and applications both at micro and macro levels. They not only complement the profit-loss sharing methods but also provide flexibility of choice to meet the specific needs of different sectors and different economic agents in the society." 35

(Ini, bagaimana pun, tidak berarti bahwa teknik pembiayaan lainnya kurang penting dan perlu dibuang. Masing-masing memiliki kegunaan dan aplikasinya sendiri baik di tingkat mikro dan makro. Teknik-teknik pembiayaan yang lain tersebut tidak hanya melengkapi metode bagi hasil (profit-loss sharing), tetapi juga menyediakan fleksibilitas pilihan untuk memenuhi kebutuhan khusus dari berbagai sektor dan pelaku ekonomi yang berbeda di masyarakat).

Pernyataan Fahim Khan tersebut terkesan tidak konsisten dengan formulasi konsepnya yang berpijak pada sistem ekonomi Islam berbasis bagi hasil. Padahal dalam konsepnya, Fahim Khan menegaskan bahwa proses pembangunan dalam ekonomi Islam pertama-tama dengan mengganti sistem bunga dengan sistem bagi untung/rugi. Maka dibolehkannya pembiayaan

${ }^{34}$ Pada prinsipnya ada lima jenis akad yang mendasari sistem pengembangan produk di bank syariah yaitu: prinsip wadiah (simpanan), prinsip syirkah (kerja sama bagi hasil), prinsip tijärab (jual beli/pengembalian keuntungan), prinsip al-ajr (pengambilan fee) dan prinsip al-qardh (biaya administrasi). Lihat: Muhammad, Sistem dan Prosedur Operasional Bank Iskam, Yogyakarta: UII Press, 2000, hlm. 5-6.

${ }^{35}$ Fahim Khan, Comparative Economics of Some Islamic Financing Tehniques, http://www.irti.org, diakses 14 Pebruari 2014. 
memamakai prinsip jual beli/muräbahah atau sewa (ijärah) yang memastikan mark-up yang jelas dan pasti dari pihak pelaku usaha yang dibiayai tanpa tergantung kondisi untung rugi usahanya, berarti upaya penyemarakan aktivitas kewirausahaan menjadi tidak maksimal dan masih mirip yang terjadi pada pembiayaan berbasis bunga yang banyak dikritik Fahim Khan.

Perbankan syariah sebagai institusi keuangan Islam menuntut ditumbuhkembangkan dengan diversifikasi produk yang tidak hanya terpaku pada musyärakah dan mudhärabah. Fahim Khan mentolerirnya bukan berarti inkonsisten dengan gagasannya yang mengidealkan prinsip bagi hasil sebagai satu-satunya basis system ekonomi Islam. Tetapi Fahim Khan mengikuti gradualitas proses pemakaian sistem berbasis bagi hasil yang menyemarakkan kewirausahaan menuju kemakmuran. Proses ini membutuhkan pengkondisian yang menyangkut kebijakan negara dan pembinaan sumber daya baik skill maupun moral. ${ }^{36}$ Pemodal dan pelaku usaha dengan didukung sistem yang tepat akan mempercepat proses penyemarakan wirausaha yang dipandang sebagai strategi Islami pembangunan ekonomi padat penduduk.

Formulasi konsep Islam untuk pembangunan ekonomi padat penduduk perpektif Fahim Khan memang menekankan strategi pembangunan ekonomi pada pengaturan institusional untuk secara langsung melibatkan orang dalam kegiatan kewirausahaan daripada strategi memanjakan kapitalis untuk menciptakan kesempatan kerja dengan upah pasti di pasar kerja. Tetapi Fahim Khan menyadari bahwa meskipun ia meyakini bahwa meskipun mekanisme tersebut sudah built-in dalam ajaran ekonomi Islam, harus diciptakan kondisi yang mendukung dan memperkuat mekanisme tersebut melalui langkah sebagai berikut:

1. Memperkuat pendidikan skill usaha dan moralitas Islami sekaligus. Kemampuan kewirausahaan adalah modal sumber daya manusia yang harus dikembangkan oleh pendidikan yang tepat. Perencanaan pendidikan yang tepat dapat berkontribusi banyak untuk mengurangi risiko wirausaha dengan terciptanya iklim sosial yang kondusif serta kesadaran bersama untuk mentaati segala aturan main. Tidak hanya pendidikan komersial, pendidikan Islam memiliki peranan penting yang

\footnotetext{
${ }^{36}$ Fahim Khan, Essays..., hlm. 208.
} 
Strategi Pembangunan Ekonomi...

tidak boleh diabaikan untuk menciptakan iklim sosial yang mendukung bisnis konstruktif serta menanamkan etika dan moral masyarakat.

2. Reformasi untuk efisiensi sistem perbankan. Perluasan akomodasi finansial melalui sistem perbankan dapat berfungsi sebagai alat yang efektif untuk meningkatkan pembiayaan bagi sumber daya manusia enterprener. Efisiensi sistem perbankan dalam menyediakan pembiayaan tersebut dalam kerangka Islam mensyaratkan reformasi substansial tidak hanya dalam struktur perbankan yang ada, tetapi pada seluruh sektor fiskal dan moneter. Dalam kerangka Islam, bank dan lembaga keuangan seharusnya diminta untuk menawarkan akomodasi keuangan hanya untuk pengusaha. Pinjaman konsumtif dari perbankan komersial hampir tidak ada karena pinjaman ini harus berupa qardh hasan (pinjaman tanpa bunga atau tanpa bagi hasil).

3. Memperkuat sistem pengawasan yang efektif. Institusi Islam hisbah harus dihidupkan kembali untuk mengawasi secara efektif norma-norma keadilan sosial ekonomi dalam perekonomian. Harga, sewa, alat-alat produksi, struktur produksi, struktur upah, pasar dan fungsinya, dan sebagainya, semua masuk dalam lingkup pengawasan lembaga ini. ${ }^{37}$

Dapat digarisbawahi bahwa konsep Islami pembanguan ekonomi padat penduduk dalam pemikiran Fahim Khan merupakan sinergi antara normativitas ajaran Islam dengan institusi yang dibangunnya. Konsep ini memadukan antara aturan larangan riba dan perintah sedekah. Larangan riba memerlukan institusionalisasi atau pelembagaan keuangan dan perbankan berbasis kemitraan berbagi untung dan rugi. Sedangkan perintah sedekah memerlukan institusionalisasi filantropi Islam dalam sistem operasionalisasi zakat, infaq dan sedekah yang efektif sebagai sistem jaminan sosial yang akan membentengi kekhawatiran kegagalan usaha. Keberhasilan institusionalisasi larangan riba dan perintah sedekah ini akan mendorong proses pembangunan dengan berbasis penyemarakan industri kecil dan menengah atau kewirausahaan dengan didukung proses pendidikan yang efektif dan sistem pengawasan yang efektif pula.

${ }^{37}$ Ibid. 


\section{Kesimpulan}

Formulasi konsep Islam tentang strategi pembangunan ekonomi menurut Fahim Khan bertumpu pada strategi perluasan aktivitas wirausaha produktif bukan bertumpu pada strategi perluasan lapangan kerja sektor formal dalam mengatasi surplus tenaga kerja dalam proses pembangunan ekonomi. Strategi ini dipandang sesuai dengan sistem ekonomi Islam berbasis kemitraan berbagi untung dan rugi (profit-loss sharing). Strategi ini berbeda dengan strategi ekonomi konvensional berbasis bunga yang menekankan akumulasi modal untuk pengembangan industri guna menyerap lebih banyak tenaga kerja. Tetapi konsep Fahim Khan masih lebih kental dengan formalisme aturan hukum Islam dari pada memperluasnya secara substansial.

Gagasan Fahim Khan dilatarbelakangi oleh pengamatannya terhadap kegagalan strategi pembangunan ekonomi di negara-negara sedang berkembang yang mengadopsi teori-teori pembangunan ekonomi yang dirumuskan oleh ahli ekonom Barat. Gagasan ini tidak terlepas dari konteks latar belakang akademik dan kiprahnya memperkenalkan sistem keuangan Islam. Dalam merumuskan gagasannya, Fahim Khan memakai metode pemikiran retrospektif yakni menelaah persoalan-persoalan ekonomi kontemporer dengan merujuk pada norma ajaran Islam untuk mencari dukungan pemecahan problem tersebut.

Pemikiran Fahim Khan tidak terlepas dari semangat penyemarakan bank syariah. Gagasannya mempromosikan keunggulan sistem perbankan berbasis bagi hasil atas sistem perbankan konvensional berbasis bunga dalam memacu pembangunan ekonomi. Meskipun Fahim Khan meyakini bahwa sistem bagi hasil lah yang memiliki pengaruh kuat untuk menciptakan dan mendorong kegiatan kewirausahaan dalam perekonomian, ia tetap mendukung tumbuh kembangnya perbankan syariah dengan diversifikasi produk yang tidak hanya terpaku pada prinsip bagi hasil saja. Ini menunjukkan bahwa Fahim Khan mengikuti gradualitas dimana proses menuju idealitas sistem bagi hasil yang menyemarakkan kewirausahaan membutuhkan penciptaan kondisi yang kondusif. 
Strategi Pembangunan Ekonomi...

\section{DAFTAR PUSTAKA}

“Authors' Biography", Journal of Islamic Economics, Banking and Finance, Volume 6, Number 2.

Asy'arie, Musa, Keluar dari Krisis Multi Dimensi, Yogyakarta: LESFI, 2001.

Azhar, Saifuddin, Metode Penelitian, Yogyakarta: Pustaka Pelajar, 1998.

Biodata of Dr. Fahim Khan - IRTI Publication, http://www.irtipms.org/Fahim\%20Khan_E.asp, diakses 10 September 2014.

BR, Arfida, Ekonomi Sumber Daya Manusia, Jakarta: Ghalia Indonesia, 2003.

Bronfenbrenner, Martin, et. al., Economics, Edisi II, Boston: Houghton Mifflin Company, 1989.

Colander, David C., Economics, Edisi V, New York: McGraw-Hill/Irwin. 2004.

Djojohadikusumo, Sumitro, Perkembangan Pemikiran Ekonomi, Dasar Teori Ekonomi Pertumbuhan dan Ekonomi Pembangunan, Jakarta: LP3ES, 1994.

Dornbusch, Rudiger, et. al., Macroeconomics, Edisi VIII. New York: McGrawHill/Irwin, 2001.

Ghazali (El), Abdel Hamid, Man is The Basis of The Islamic Strategy For Economic Development, Jeddah: IRTI-IDB, 1994.

Hall, Robert E. dan John B. Taylor, Macroeconomics Theory, Performance, and Policy, Edisi II. New York: W. W. Norton \& Company, 1988.

Haq, Mahbub, Reflections on Human Development. How The Focus of Development Economics Shifted from National Income Accounting to People Centred Policies, Told by One of The Chief Architects of The New Paradigm, New York: Oxford Univ. Press, 1995.

Irawan dan Suparmoko, Ekonomika Pembangunan, Yogyakarta: BPFE, 1996.

Jazairi (al), 'Abd al-Rahman, Kitab al-Fiqh 'alā Maŗ̧āhib al-Arba'ah, Juz III, Beirut: Dār al-Kutub al-'Ilmiyyah, 1990.

Kahf, Monzer, The Islamic Economy: Analytical of The Functioning of The Islamic Economic System, terj. Machnun Husein, "Ekonomi Islam (Telaah Analitik terhadap Fungsi Sistem Ekonomi Islam), Yogyakarta: Pustaka Pelajar, 1995. 
Khan, Fahim, "Comparative Economics of Some Islamic Financing Tehniques”, http://www.irti.org/, diakses 14 Pebruari 2014.

, Essays in Islamic Economics, Leicester: The Islamic Foundation, 1995.

Mahyudi, Akhmad Mahyudi, Ekonomi Pembangunan dan Analisis Data Empiris, Jakarta: Ghalia Indonesia, 2004.

McConnell, Campbell R., et. al., Contemporary Labor Economics, Edisi VII. New York: McGraw-Hill/Irwin, 2006.

Meier, Gerald M., Leading Issues in Economic Development, Edisi V, New York: Oxford University Press, 1989.

Muhammad, Sistem dan Prosedur Operasional Bank Iskam, Yogyakarta: UII Press, 2000 .

Nugroho, Wahyu Budi, "Industrialisasi Orde Baru Tumbuh dengan Kemiskinan”,http://kolomsosiologi.blogspot.com/2011/03/industria lisasi-orde-baru.html, diakses 12 Maret 2011.

Perkins, Dwight H., Steven Radelet dan David L. Lindauer, Economics of Development, Edisi VI, New York : W.W. Norton \& Company, Inc., 2006.

Qahf, Muhammad Mundhir, The Islamic Economy: Analytical of the Functioning of the Islamic Economic System, Plainfield, Ind.: Muslim Students Association of U.S. and Canada, 1978.

Ravianto, J., Orientasi Produktivitas dan Ekonomi Jepang, Apa Yang Harus Dilakukaan Indonesia?, Jakarta: UI Press, 1986.

Samuelson, Paul A. \& William D. Nordhaus, Edisi ke-18. New York: McGraw-Hill/Irwin, 2005. Schiller, Bradley R., The Economy Today, ninth edition. New York: McGraw-Hill/Irwin, 2003.

Shatzmiller, Maya, "Economic Performance and Economic Growth in the Early Islamic World", Journal of the Economic andSocial History of the Orient, 54 (2011) 132-184.

Siddiqi, Muhammad Nejatullah, Issues in Islamic Banking, terj. Asep Hikmat Suhendi dari judul asli "Bank Islam", Bandung: Penerbit Pustaka, 1984.

Smith, Daniel, "The Role of Entrepreneurship in Economic Growth", Undergraduate Economic Review, Vol. 6 [2010], Iss. 1, Art. 7, Digital 
Strategi Pembangunan Ekonomi...

Commons@IWU, 2010, h.1, http://digitalcommons.iwu.edu/cgi/ viewcontent.cgi?article $=1064 \&$ context $=$ uer, diakses 8 Agustus 2014 .

Soeroto, Strategi Pembangunan dan Perencanaan Tenaga Kerja, Yogyakarta: Gadjah Mada University Press, 1986.

Sukirno, Sadono, Makroekonomi Teori Pengantar, Jakarta: PT RajaGrafindo Persada, 2006.

Swasono, Sri-Edi, Menolak Neoliberalisme dan Membangun Ekonomi Nasional, Yogyakarta: PUSTEP-UGM, 2010.

Tjokroamidjojo, Bintoro \& Mustopadidjaya, Pengantar Pemikiran tentang Teori dan Strategi Pembangunan Nasional, Jakarta: Haji Massagung, 1988.

Todaro, Michael P. Economic Development, Edisi VI, New York: AddisonWesley Publishing Company, Inc., 1997.

, Economic Development in The Third World, Edisi IV, New York: Longman. 